\title{
The Perspective of Indonesian Teachers on the Google Classroom Usage in Blended Teaching
}

\author{
Fatimatus Suhroh $^{1}$, Bambang Yudi Cahyono ${ }^{2}$ \\ ${ }^{1}$ SMKS Kesehatan Yannas Husada Bangkalan \\ ${ }^{2}$ Pendidikan Bahasa Inggris-Universitas Negeri Malang
}

\begin{tabular}{l}
\hline INFO ARTIKEL \\
\hline Riwayat Artikel: \\
Diterima: 01-04-2020 \\
Disetujui: 20-10-2020 \\
\hline
\end{tabular}

\section{Kata kunci:}

teachers' perspective,

google classroom;

blended teaching;

perspektif guru;

google classroom;

blended teaching

\begin{abstract}
Google Classroom is a kind of platform that teachers and students have come to know about. One of the learning processes achieved with google classroom is to blend the style of learning. Blended teaching is one of the teaching processes which is done not only inside the class (offline) but also outside the class (online). The study aims to impose the perspective of Indonesian teachers on the usage of Google Classroom. The study is performed through a qualitative research design. The sample of the study, which uses a survey method through a google form, consisting of forty teachers throughout Indonesia who have administered Google Classroom in their classroom for at least one semester. The data acquired has been put through a comprehensive analysis by categorizing and highlighting the data. The findings showed that almost all the teachers used blended teaching and it had three of the most beneficial usage which is accessibility, as a means of communication and data analysis. The significant challenges on the usage of Google Classroom were in the internet connection and online submitted assignments. They assumed that the overall highlights on Google Classroom usage can be effective and improved for future features.
\end{abstract}

ABSTRAK

\begin{abstract}
Abstrak: Google Classroom adalah sebuah platform yang banyak diketahui oleh para guru dan siswa. Salah satu proses pembelajaran yang dicapai dengan google classroom adalah untuk memadukan gaya belajar. Pembelajaran campuran (blended learning) adalah salah satu proses pengajaran yang dilakukan tidak hanya di dalam kelas (offline) tetapi juga di luar kelas (online). Penelitian ini bertujuan untuk mengetahui perspektif guru Indonesia tentang penggunaan Google Classroom. Penelitian dilakukan melalui desain penelitian kualitatif. Sampel penelitian, yang menggunakan metode survei menggunakan google form, terdiri dari empat puluh guru di seluruh Indonesia yang telah menerapkan Google Classroom di kelas mereka selama setidaknya satu semester. Data yang diperoleh telah dimasukkan melalui analisis yang komprehensif dengan mengategorikan dan menganalisis pokok data. Temuan menunjukkan bahwa hampir semua guru menggunakan pengajaran campuran dan memiliki tiga penggunaan yang paling bermanfaat yaitu aksesibilitas, sebagai sarana komunikasi dan analisis data. Tantangan yang signifikan dalam penggunaan Google Classroom adalah dalam koneksi internet dan penugasan yang dikirimkan secara online. Mereka berasumsi bahwa sorotan keseluruhan pada penggunaan Google Classroom dapat efektif dan ditingkatkan untuk fitur di masa depan.
\end{abstract}

\author{
Alamat Korespondensi: \\ Fatimatus Suhroh \\ SMKS Kesehatan Yannas Husada Bangkalan \\ Jalan Letnan Singosastro 3 Kraton Bangkalan \\ E-mail: misstitik7379@gmail.com
}

In the face of globalization, information communication technologies (ICTs) play an extremely important role in foreign language learning and teaching (Fonseca \& Peralta, 2019). ICT will support teachers in the global requirements for the substitution of traditional teaching approaches by technical resources and learning facilities (Ghavifekr \& Rosdy, 2015). The problem of the use of modern teaching and learning information and communication technologies is of major importance (Arkorful \& Abaidoo, 2014). Most higher education institutions are becoming increasingly common and provide complete online and/or hybrid / mixed training that incorporate online education with face-to-face instruction (Sun \& Chen, 2016). The essence of the relationships between students and teachers has been modified by modern technologies (Osman, 2017).

GSuite for Education subscribes to educational institutions and google launched Google Classroom as an e-learning platform (Bayarmaa \& Lee',2018). Google Classroom is a free web-based learning software or platform used for teacherlearner collaboration (Mafa, 2018). Google Classroom is a blended education platform for schools that simplifies the process without paper by designing, distributing and grading assignments (Wisniewski, 2018). Google is developing a free web-based 
educational platform. Including Google Docs, Gmail, and Google Calendar, Classroom integrates GSuite with all GSuite education services. It encourages paperless instruction to improve assignments, it facilitates cooperation to make teaching more efficient and meaningful (Ventayen, Estira, Guzman, Cabaluna, \& Espinosa, 2017).

The distance, online or blending learning style of teaching offers many advantages over the traditional classroom teaching style. Distance education is a form of training that separates teachers and students and provides telecommunications learning content (Sukmawati \& Nensia, 2019). Thus, many teachers, especially in Indonesia, have started using Google Classroom to help with classroom management. Teachers can adjust tasks and due dates and prepare material for the convenience of teachers (Kaur \& Erturk, 2017). This classroom helps teachers to quickly set up and coordinate activities, receive input and interact effectively with their students (Shaharanee, Jamil, and Rodzi, 2016).

Blended learning itself is a formal education program in which a student learns, at least partially, through online content delivery and instruction with some element of student control over time, pace, and/or space, and at least partially at a supervised brick-and-mortar location away from home (Graham, 2006). Also, blended learning has been described as a teaching model, according to Kanuka, Brooks, and Saranchuck (2009), which eliminates the time, place, and situational barriers while allowing high-quality interactions between teachers and students. Blending is essentially a new higher education model that institutions pursue in a variety of ways, including increasing access and improving the quality of learning (Sen, 2011). Blended learning incorporates ways of direct and indirect online learning with typically the internet and intranet and, in traditional classes, indirect learning takes place concurrently (Oweis, 2018).

Zhang and Han (2012) pointed out that the term "blended learning" has an increased frequency not only in academics but also in incorporation circles. Blended learning itself offers a traditional way of learning which is combined with one-to-one based learning. As also mentioned by Saliba, Rankine, and Cortez (2013), mixed learning is a combination of face-to-face and online interactions by utilizing and integrating ICT in which it uses a strategic and systematic approach. Thus, Bondarenko, Mantulenko, \& Pikilnyak, 2018) stated that in Google Classroom interactions take place not only in the form of distance learning but also in the conventional in-class training via e-mail, e-conferences and other internet communication resources ("student-student," "student-student groups," "teachers - student," “teachers - student groups"). The different definitions of blended learning, therefore, show the complexity and intensity of this form of learning (Uğur, Kurbanoğlu, \& Akkoyumlu, 2011).

Mixed learning's most influential advantages are its accessibility, flexibility in scheduling students, and adaptability to work (Gallagher, Dobrosielski-vergona, Wingard, \& Williams. 2005). Due to its advantages, there are so many practitioners, lecturers, and teachers who are interested in looking into ways to implement it. Seminars, conferences, webinars, and online training from the SEAMEO Regional Open Learning Center (SEAMOLEC) helps SEAMEO Member Countries identify educational problems and find alternative solutions to the sustainable development of human resources through the dissemination and effective use of Open and Distance Learning (ODL). Google classroom offers several advantages for students and teachers as a free online learning platform. Lynch (2018), points out the following benefits of using Google Classroom, namely; accessibility, exposure, paperless, time saver, communication, collaboration, engagement, differentiation, feedback, and data analysis. Besides, Chehayeb (2015), Google Classroom Software Engineer mentions that they built classroom " to save time". He has noted that this classroom is a time saver which features are highlighting in exporting grades to Google Sheets, the grade point scale is easier to update, the grade entry keyboard navigation, the grading page name sorting, etc.

From the students' feedback and Heggart \& Yoo (2018) reflection, they stated that several concepts found when using GAFE (Google Apps for Education) in a tertiary classroom environment were identified. These concepts provide a framework for teachers in tertiary institutions to make the best use of available technologies in pedagogical practice. Those concepts are accessibility, collaboration, student voice/agency, and the pace. Then,

Based on Iftakhar (2016) research findings, it is stated that all teachers encourage the students to enroll in the created class by using the code. They also strongly motivate their learners' to use it regularly. Furthermore, one teacher mentions that Google Classroom features to enable him and his learners to have a better interaction. Another teacher gives comments about Google Classroom which is very helpful in completing the assigned syllabus. He/she said that because of political issues or national holidays, it's very difficult to finish the syllabus on time. But through Google Classroom, one teacher can conduct the class virtually from the distance and any condition. So, Google Classroom plays a key role to a higher education system where technology is badly needed in the recent days and it becomes popular among students as they can get all reading materials and resources, lesson plan, course outline beforehand. Thus, he/she can construct his students very easily.

Fitriningtiyas, Umamah, and Sumardi (2018) informed that the issue analysis can be solved by studying history context through google classroom media. As stated in Balley (2017) that years of experience, grade level assignment, and subject matter are having positive teachers' perceptions of the technology-based Google Classroom. Here, There is an important relationship among those three factors to the teachers' perceptions of the technology-based Google Classroom and their perceptions' were dependent upon them. From the background, this study examined the Indonesian teachers' perspective on Google Classroom usage in blended teaching. It has three questions for research as follows (1) what are the Indonesian teachers' perspectives on the most beneficial usage of Google Classroom in blended teaching?; (2) what are the Indonesian teachers' perspectives on the challenges in implementing Google Classroom?; (3) what are the Indonesian teachers' perspectives on the overall highlights of Google Classroom? 


\section{METHOD}

The study is performed through a qualitative research design. The study sample, which uses a survey method through Google Form, consisting of 40 Indonesian teachers who implemented Google Classroom in their classroom for at least one semester. It is shown in table 1.

\begin{tabular}{|c|c|c|}
\hline No & Provinces & Numbers \\
\hline 1 & East Java & 24 \\
\hline 2 & West Java & 4 \\
\hline 3 & Central Java & 2 \\
\hline 4 & Banten & 1 \\
\hline 5 & DKI Jakarta & 2 \\
\hline 6 & Maluku & 1 \\
\hline 7 & Lampung & 1 \\
\hline 8 & South Lampung & 1 \\
\hline 9 & DI Yogyakarta & 1 \\
\hline 10 & South Kalimantan & 1 \\
\hline 11 & South Sulawesi & 1 \\
\hline \multirow[t]{2}{*}{12} & Bengkulu & 1 \\
\hline & Total & 40 \\
\hline
\end{tabular}

In just a few minutes, users can create surveys to ask our customers or employees about our products or services (Datascope, 2018). Google Form allows us to include different types of questions such as short answers, paragraphs, multiple selections, verification boxes, pull-down, linear scale, a grid of several options, among others.

The participants consist of 25 females and 15 males of teachers in different fields of teaching which are 19 teachers from EFL teachers and the rest are from other fields namely; 12 from adaptive teachers, 3 from normative teachers, 4 from productive teachers and 2 from classroom teachers in elementary school. This survey specifically dealt with the usage of Google Classroom which has been applied by the teachers to the students In the process of teaching and learning. The questions in the survey covered various aspects of Google Classroom including benefits, challenges in implementing Google Classroom and the overall highlights of Google Classroom. Since the survey was given to not only English teachers but also teachers from other fields, so the questionnaires are given in two languages which are the English language and Bahasa Indonesia.

Prior to the survey, some questions were given to the participants in which it can acquire the answers that can be analyzed as the data. There are three parts of the questions that were given, namely; first is about the benefits of Google Classroom. Ten benefits are mentioned in the questions including its accessibility, exposure, paperless, time saver, communication, collaboration, engagement, differentiation, feedback, and data analysis.

Furthermore, in the second part, it is about challenges in implementing Google Classroom, namely; The challenges students face, the challenges teachers face and the challenges in blended teaching related to Google Classroom in which it uses online or face-to-face teaching. The third, it concerns about the overall highlights, namely; the effectiveness of Google Classroom, the experience in using Google Classroom and the ideas in improving Google Classroom features. All of the three parts questions were answered by giving yes or no answer in the first part, choosing more than one answer in the third part and a short explanation in the last part. Because the teachers are from English teachers and other fields, so they can give responses either in English or Bahasa Indonesia. All the questions from the survey in Appendix A are attached.

After spreading the survey via link by using a smartphone to the teachers throughout Indonesia which is done online through Google Form, the data was analyzed and reviewed through a spreadsheet that can be exported into Ms. Excel form. Furthermore, the data from Google Form itself can be extracted in the shape of the diagram and chart, so that, it can make the researcher easier in analyzing the whole data. The questionnaires from the survey were adapted from Azhar and Iqbal (2018) and developed to suit this study's purpose. Besides, Al-Maroof and Al- Emran (2018) also made a similar questionnaire and it is modified by the researcher to be used to answer the research questions. All of the 40 teachers throughout Indonesia responded to the questions which are done in the online survey.

\section{FINDINGS}

The results of the study refer to the three research questions. The results reveal the most beneficial benefits on the Google Classroom usage, the challenges in implementing Google Classroom and the overall highlights of Google Classroom. 


\section{The Indonesian Teachers' Perspectives on the Most Beneficial Usage of Google Classroom in Blended Teaching}

The first question of the research is addressed the Indonesian teachers' perspectives on the most beneficial usage of Google Classroom in blended teaching. There were ten questions related to the ten benefits of Google Classroom usage. The teachers should answer the questions by giving "Yes" or "No" answer in relation to the questions which give a beneficial usage or not. The teachers' answers to the ten questions of the ten benefits of Google Classroom are shown in table 2.

Table 2. The Indonesian Teachers' Perspectives on the Most Beneficial Usage of Google Classroom in Blended Teaching

\begin{tabular}{clcccc}
\hline \multirow{2}{*}{ No } & \multirow{2}{*}{ Questions } & \multicolumn{2}{c}{ "Yes" } & \multicolumn{2}{c}{ “No" } \\
\cline { 3 - 6 } & N & \% & N & \% \\
\hline 1 & Accessibility & 40 & 100 & - & - \\
2 & Exposure & 39 & 97.6 & 1 & 2.4 \\
3 & Paperless & 39 & 97.6 & 1 & 2.4 \\
4 & Time saver & 37 & 92.7 & 3 & 7.3 \\
5 & Communication & 40 & 100 & - & - \\
6 & Collaboration & 38 & 95.1 & 2 & 4.9 \\
7 & Engagement & 38 & 95.1 & 2 & 4.9 \\
8 & Differentiation & 36 & 90.2 & 4 & 9.8 \\
9 & Feedback & 39 & 97.6 & 1 & 2.4 \\
10 & Data analysis & 40 & 100 & - & - \\
\hline
\end{tabular}

Table 2 shows that the Indonesian teachers have positive perspectives on the benefits of Google Classroom. It is shown from the ten benefits of Google Classroom in which the whole teachers who answer "Yes" are more than 50\% of each benefit. This means that Google Classroom gives lots of benefits on the usage itself.

The most commonly occurred with $100 \%$ of "Yes" answers from the 40 teachers are shown in the accessibility (Question \#1), as a mean of communication (Question \#5) and data analysis (Question \#10) with the total number of 40(100\%), $40(100 \%)$, and $40(100 \%)$ of the teachers. It is shown in figure 1.

\section{0 tanggapan}

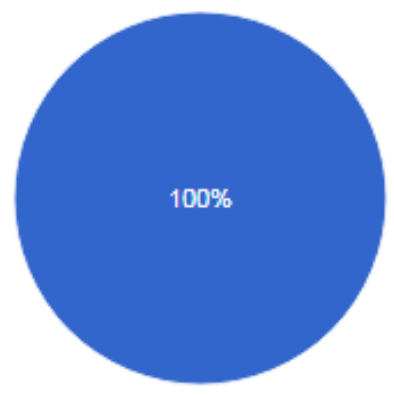

Figure 1. Accessibility, As a Mean of Communication, Data Analysis

It can be concluded that the most beneficial usage on the Google Classroom in blended teaching is mostly chosen in the accessibility, as a means of communication and the data analysis.

\section{The Indonesian Teachers' Perspectives on the Challenges in Implementing Google Classroom}

The second research question concerns about the Indonesian teachers' perspectives on the challenges in implementing Google Classroom. Three main items consist of the challenges students face, the challenges teachers face and the challenges in blended teaching related to Google Classroom. The teachers could give more than one answer related to each item. It is provided a space for the teachers to write the additional challenges which are occurred in their area if it is necessary. Then, the teachers' answers to the three items which consist of them are shown in table 3. 
Table 3. The Indonesian in Implementing Google Classroom

\begin{tabular}{ccccc}
\hline No & \multicolumn{1}{c}{ Questions } & N & \% \\
\hline $\mathbf{1}$ & Challenges faced by students & & \\
& $\square$ & Internet Connection & 37 & 92.5 \\
& $\square$ & There is no specific folder for students to save files & 10 & 25 \\
& $\square$ & No students involvement & 3 & 7.5 \\
& $\square$ & Difficult for students to adjust in using Google Classroom & 15 & 37.5 \\
& $\square$ & Difficult for students to upload files, videos, assignments, etc & 11 & 27.5 \\
\hline $\mathbf{2}$ & Challenges faced by teachers & & \\
& $\square$ & Internet Connection & 32 & 80 \\
& $\square$ & Unable to make it interactive & 13 & 32.5 \\
& $\square$ & Difficult for teachers to adjust in using Google Classroom & 8 & 20 \\
& $\square$ & Difficult for teachers to upload files, videos, assignments, etc & 4 & 10 \\
& $\square$ & Limited online materials & 12 & 30 \\
\hline 3 & Challenges in blended teaching related to Google Classroom & & \\
& $\square$ & Face to face materials & 22 & 55 \\
$\square$ & Online Materials & 31 & 77.5 \\
$\square$ & Face to face explanation & 20 & 50 \\
$\square$ & Online explanation & 20 & 50 \\
$\square$ & Face to face given assignments & 17 & 42.5 \\
$\square$ & Online given assignments & 30 & 75 \\
$\square$ & Face to face submitted assignments & 20 & 50 \\
$\square$ & Online submitted assignments & 33 & 82.5 \\
$\square$ & Face to face assessments & 20 & 50 \\
$\square$ & Online assessments & 29 & 72.5 \\
$\square$ & Face to face feedback & 20 & 50 \\
$\square$ & Online feedback & 27 & 67.5 \\
\hline
\end{tabular}

Table 3 shows that the Indonesian teachers feel so challenging on the Google Classroom usage that there are several issues that they face when they implement it. It is shown that the majority of teachers employ different challenges and different implementation in blended teaching itself. The first item, the challenges students face which mostly occurred is the internet connection (Choice \#1) with the total number of 37 (92.5\%) of the teachers.

From these challenges which are faced by the students, Teacher 1 stated that "Students sometimes did not take care of the instruction which leads them to the confusion in completing the task", and in line with it Teacher 25 stated that "Students need more time to learn and adapt on Google Classroom since they have to master in using computer or mobile phone first and teachers should give a background knowledge that the technology is not only can be used as entertainment but also education". Meanwhile, Teacher 5 stated that "The media that students have is still not in accordance with the standard one". Furthermore, Teacher 9 stated that "In a rural place, sometimes the implementation is failed because of the internet link cannot catch the line, even it is supplied by many providers".

The second item, the challenges teachers face which mostly occurred is the internet connection (Choice \#1) with the total number of $32(80 \%)$ of the teachers. From these challenges which are faced by the teachers, Teacher 1 stated that "There are huge numbers of materials both online or offline, those are the problems and in screening appropriate materials are not an easy task". Furthermore, Teacher 31 stated that "The use of applications and abilities of teachers who are lacked in managing online learning" and similar to that, Teacher 5 stated that "Not all students have a laptop or mobile phones which support the application so that the learning cannot be maximized". Regarding the process of teaching and learning, Teacher 9 stated that "She can not do face to face explanation in order to cover the misunderstanding of students' comprehension related to the materials".

The last item is the challenges in blended teaching related to Google Classroom. There are three key points in the blended teaching which are mostly chosen by the teachers namely; online submitted assignments (Choice \#8), online Materials (Choice \#2), and online given assignments (Choice \#6) with the total number of $33(82.5 \%), 31(77.5 \%)$, and 30 (75\%) of the teachers.

Related to the challenges in blended teaching on Google Classroom, Teacher 1 stated that "It depends on how teachers perceive the difficulty of the students' face. At some points, materials can be given online, and in face to face meetings, teachers can focus on the students who are having trouble". So, it may be assumed that she prefers online and encounter face to face. In one case, the materials can be given online but in another case, in face to face meetings, the teachers focus on the difficulties which are faced by the students so that they can obtain more understanding taken from face to face meetings rather than online meetings. 


\section{The Indonesian Teachers' Perspectives on the Overall Highlights of Google Classroom}

The third question of research relates to the overall highlights of Google Classroom. Three main items consist of the effectiveness of Google Classroom, the experience in using Google Classroom, and the improvement for Google Classroom. The teachers could give their explanations concerning each item.

Regarding the effectiveness of Google Classroom, some teachers assume that paperless, exposure, time saver, engagement, feedback, and data analysis are the most effective benefits they got. They seem to be more efficient in teaching by using Google Classroom. Teachers 12 and 34 stated that when they have a duty outside the school, for instance; MGMP or Education Training, Google Classroom plays a major role in such effectiveness mentioned. They can handle the online process of teaching and learning using this application so that both responsibilities can be achieved at the same time. Moreover, Teachers 7 and 13 also stated that in the case of students' job training especially vocational high school, the process of teaching and learning still can be conducted as well as face to face conversation because all the students could go to Google Classroom anywhere anytime.

In line with the facilities of the school have, for example; internet connection, computer or laptop, and online materials, some teachers stated that they can use Google Classroom for the process of teaching and learning and it correlates to the teachers' capability in managing Google Classroom itself. Teacher 25 stated that when teachers and students are capable of using technology, so they do not need more time to learn basic things like how to use a computer or mobile phones.

In experiencing Google Classroom, one teacher with the others have different things to tell. It is still interrelated with the effectiveness itself. Some teachers said they were able to access Google Classroom everywhere which is in line with accessibility. Furthermore, Teacher 37 said that the students are very interested and happy to learn English moreover the teaching is easy to do and they can submit their tasks quickly without cheating. Teacher 25 stated that Google Classroom is very suitable for Vocational High School students, especially for software engineering students since they have already known about how to use the technology. So, this Google Classroom implementation is very easy for them to be applied to. Furthermore, Teacher 7 stated that the best experience in using Google Classroom is that the teacher can give online assignments and explanation to the online material by accessing Youtube when the teacher can not join the class, so the students can progress the subject by themselves.

Some teachers expect something new from Google Classroom even though it is already suited to the process of teaching and learning. Several improvements to Google Classroom were arisen by those teachers. Some teachers thought that Google Classroom is already fulfilled their needs. But they have another expectation for its development. Like Teacher 34 said that it should have the improvement on the features such as in making task which can be directly accessed in Google Classroom. Furthermore, Teacher 1 and 26 expect that Google Classroom will be fulfilled by Video Conference like in Cisco Webex with the free charge one and Teacher 27 hopes that Google Classroom will be added with Voice note like in Whatsapp.

Meanwhile, Teachers 33 and 40 are expecting more on the education terms, for example; Google Classroom will be completed with the test analysis in scoring so that the teacher can be easier in analyzing the students' scores. Then, they hoped Google Classroom will give another improvement which is an online quiz that can be directly accessed from Google Classroom itself but not from other program or link which is inserted in it. So, Google Classroom has one feature in which teachers can make online quizzes directly from this application.

Surprisingly, Teacher 17 wished that it will be great if Google Classroom is able to be used offline which means that it does not need an internet connection due to in some cases internet connection is still limited in some areas. If it can be used offline, all teachers and students moreover in rural areas can use Google Classroom and get the benefits of it. This expectation is beyond some teachers might think but it should get a big hand due to its willingness to the improvement of Google Classroom.

\section{DISCUSSION}

\section{Discussion of the Indonesian Teachers' Perspective on the Google Classroom usage in Blended Teaching}

This study has been discussing the Indonesian teachers' perspective on Google Classroom usage in blended teaching. The results of the analysis are obtained in reference to answer the three research questions.

The first question of research concerns the benefits of Google Classroom in blended teaching. Lynch (2018) points out the benefits of using Google Classroom which are accessibility, exposure, paperless, time saver, communication, collaboration, engagement, differentiation, feedback, and data analysis. The result of the study shows that the most beneficial usage of Google Classroom is inaccessibility, as a means of communication and data analysis. By using Google Classroom, it is very helpful to accomplish the assigned syllabus (Iftakhar, 2016) and can access the class virtually wherever and whenever the teachers' are. Furthermore, besides its usage can be used for announcing the assignment or for submitting it, (Iftakhar, 2016) stated that it can also be used to share comments from the grading based on the assignment itself. So, the teachers can give feedback to let the students know their assignment results.

Relating to the second research question, the result from the challenges in implementing Google Classroom is in the internet connection which is mostly faced not just by students, but teachers as well. Azhar and Iqbal (2018) stated that the students were also difficult to upload online materials and they faced obstacles in editing them. Thus, they suggested that it can be a problem in using excessive use of such technology, so it should be used as effectively as it could be. Furthermore, Iftakhar 
(2016) assumed that low internet speed will be problematic in implementing Google Classroom. Another challenge in implementing Google Classroom is in blended teaching. Three main points exist in blended teaching which are mostly chosen by the teachers namely; online submitted assignments, online materials, and online given assignments. As Azhar and Iqbal (2018) said, Google Classroom helps in uploading the whole materials for the class, so it means that the teachers can upload the whole materials for the whole class. Furthermore, Iftakhar (2016) assumed that Google Classroom is as collaborative learning. The teachers can use assignment feature and the students can directly submit it, then the teachers can give them online feedback or grading and comments on the assignment itself.

In addition to the overall highlights, the result in the Google Classroom efficiency is in the paperless, exposure, time saver, engagement, feedback, and data analysis. Azhar and Iqbal (2018) mentioned that Google Classroom has facilitated the teachers and the students for the process of teaching and learning, then it is sort of an average tool which means it is considered $50 \%$ to succeed and $50 \%$ of failure. Furthermore, it can eliminate the hard copies of assignments so that is why Google Classroom is paperless. Another result from this study is in experiencing Google Classroom and it is still interrelated with the effectiveness itself. Some teachers said they could have access to Google Classroom anywhere anytime, then the students are very interested and happy to learn English moreover the teaching is easy to do and they can submit their tasks quickly without cheating. It is stated by (Iftakhar, 2016) that by using Google Classroom, teachers can easily handle a large number of students and the students themselves are very positive in this. But it is not in line with the students' assignment which is submitted without cheating, Iftakhar (2016) stated that almost all the teachers agree that the students' assignments are plagiarized. They only download the materials from other websites or resources and they can edit it. In addition to the improvement in Google Classroom, the result from this study are various, namely; about the improvement on the features, can be used as video conference, online quizzes and can be accessed offline. It is similar to (Azhar and Iqbal, 2018), they mentioned that Google Classroom enables students and teachers to interact and discuss. Furthermore, in quizzes too, it is stated that the improvement is about the instant quizzes which can be used by the teachers through Google Classroom.

\section{CONCLUSIONS}

The focus of this study is on the Indonesian teachers' perspective on Google Classroom usage in blended teaching. Overall, Google Classroom is one very beneficial online platform in which teachers can use it in blended teaching. At a glance, blended teaching seems to be difficult when it is implemented by using the online platform, but apparently, as the time goes on, with the improvement of the technology, teachers are more appropriate using online platforms especially Google Classroom in their process of teaching and learning. The findings indicate that positive perceptions from the teachers help themselves in some ways to develop their process of teaching and learning more effective and interactive. Challenges sometimes occur in the implementation of every online platform especially this platform (Google Classroom). Rather than looking at the problematic issues, the effectiveness of using Google Classroom makes them eager to share their ideas in improving it and makes it more sophisticated.

\section{REFERENCES}

Abdelrahman, Basher, S., Chauhan, O., Khalil, S., \& Zeiadee, M. (2017). The Impact of Google Classroom Application on the Teaching Efficiency of Pre-Teachers. International Journal of Social Sciences and Education, 2(2), 33-48, http://dx.doi.org/10.1016/j.compedu.2016.11.005

Al-Maroof, R. A. S. \& Al-Emran, M. (2018). Students' Acceptance of Google classroom: An Exploratory Study Using PLSSEM Approach. International Journal: Emerging Technologies in Learning, 13(6), 112-123. https://doi.org/10.3991/ijet.v13i06.8275.

Arkorful, V. \& Abaidoo, N. (2014). The Role of E-Learning, The Advantages, and Disadvantages of its Adoption in Higher Education. International Journal of Education and Research, 12(1), $29-42$.

Azhar, K. A. \& Iqbal, N. (2018). Effectiveness of Google Classroom: Teachers' Perceptions. Prizen Social Science Journal, $2(2), 52-66$.

Balley, T. D. (2017). Teacher Perceptions of a Technology-Based Google Classroom. Unpublished Dissertation. CarsonNewman University.

Bondarenko, O. V., Mantulenko, S. V., and Pikilnyak, A. V. (2018). Google Classroom as a Tool of Support of Blended Learning for Geography Students.

Bayarma, N. \& Lee', K. (2018). A Study on the Application of Google Classroom for Problem-Based Learning. Journal of the Korea Academia-Industrial Cooperation Society, 19(7), 81-87. https://doi.org/10.5762/KAIS.2018.19.7.81

Fitriningtiyas, D. A., Umamah, N., \& Sumardi. (2019). Google classroom: As a Media of Learning History. IOP Conference Series: Earth and Environmental Sciences, 243(1). DOI:10.1088/1755-1315/243/1/012156

Fonseca, K. A. B. \& Peralta, F. S. (2019). Google classroom: An effective Virtual Platform to teach writing in an EFL composition course. International Journal of English Language Teaching, 6(1), 27-35 https://doi.org/10.5430/ijelt.v6n1p27

Gallagher, J. E., Dobrosielski-vergona, K. A., Wingard, R. G., \& Williams, T. M. (2005). Web-based vs. Traditional Classroom Instruction in Gerontology: A Pilot Study, 79(3), 1-10. 
Ghavifekr, S. \& Rosdy, W. A. W. (2015). Teaching and Learning with Technology: Effectiveness of ICT Integration in Schools. International Journal of Research in Education and Science (IJRES), 1(2), 175-191, https://doi.org10.21890/ijres.23596

Heggart, K. R., \& Yoo, J. (2018). Getting the Most from Google Classroom: A Pedagogical Framework for Tertiary Educators. Australian Journal of Teacher Education, 43(3), 140-153.

Iftakhar, S. (2016). Google Classroom: What Works and How? Journal of Education and Social Sciences, 3(2), 2-18.

Mafa, K. R. (2018). Capabilities of Google Classroom as a Teaching and Learning Tool in Higher Education. International Journal of Science Technology \& Engineering (IJSTE), 5(11), 3-8.

Oweis, T. I. (2018). Effects of Using a Blended Learning Method on Students' Achievement and Motivation to Learn English in Jordan: A Pilot Case Study. Hindawi Education Research International. https://doi.org/10.1155/2018/7425924

Sen, T. K. (2011). Application of Blended and Traditional Class Teaching Approach in Higher Education and the Students Learning Experience. International Journal of Innovation, Management and Technology, 2(2), http://dx.doi.org/10.7763/IJIMT.2011.V2.113

Shaharanee, I. N. M., Jamil, J. M., and Rodzi, S. S. M. (2016). The Application of Google Classroom as a Tool for Teaching and Learning. Journal of Telecommunication, Electronic, and Computer Engineering. 8(10), 5-8, https://doi.org/10.1063/1.4960909

Sukmawati, S., \& Nensia, N. (2019). The Role of Google Classroom in ELT. International Journal for Educational and Vocational Studies, 1 (2), 142-145, https://doi.org/10.29103/ijevs.v1i2.1526

Sun, A., \& Chen, X. (2016). Online Education and its Effective Practice: A Research Review. Journal of Information Technology Education: Research, 15(2016), 157-190.

Uğur, B. Y., Kurbanoğlu, S., Akkoyunlu, B. (2011). Students' Opinions on Blended Learning and its Implementation in Terms of their Learning Styles. Education and Information Technologies. DOI: 10.1007/s10639-009-9109-9

Ventayen, R. J. M., Estira, K. L. A., Guzman, M. J. D., Cabaluna, C. M., \& Espinosa, N. N. (2018). Usability evaluation of google classroom: Basis for the Adaptation of Gsuite E-Learning Platform. Asia Pasific Journal of Education, Arts and Sciences, 5(1), 47-51.

Wisniewski, J. (2018). What exactly is google classroom what are its benefits? Boston University. Accessed on October $2^{\text {nd }}$, 2018. https://www.quora.com/What-exactly-is-Google-Classroom-What-are-its-benefits.

Zhang, W., \& Han, C. (2012). A Case Study of the Application of a Blended Learning Approach to Web-Based College English Teaching Platform in a Medical University in Eastern China. Theory and Practice in Language Studies, 2, $1961-1970$. https://doi.org/10.4304/tpls.2.9.1961-1970 